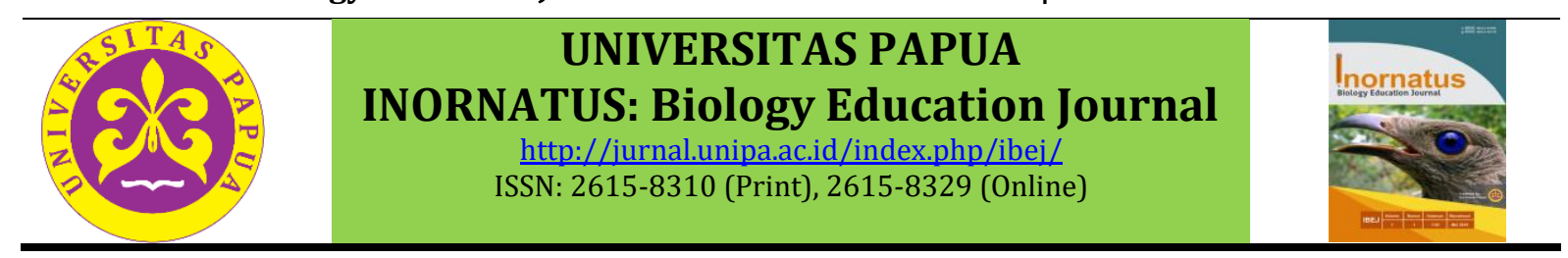

\title{
Application of problem-solving learning models to improve the activity and students' learning outcomes of SMA Kristen YABT Manokwari
}

\section{Penerapan model pembelajaran problem solving untuk meningkatkan keaktifan dan hasil belajar peserta didik SMA Kristen YABT manokwari}

\author{
Nengsi Samara ${ }^{1}$, Aksamina M. Yohanita ${ }^{2 *}$, I. Iwan ${ }^{3}$ \\ 1 Pendidikan Biologi FKIP Universitas Papua \\ *korespondensi penulis : b.iwan@unipa.ac.id
}

\begin{abstract}
The study aims to improve students activity and achievement cognitive in glade XI IPA Kristen YABT Manokwari school year 2017/2018 on the material of Human Circulation System by applying Problem Solving Learning. Classroom action research is conducted in two cycles, each cycle consists of four stages of planning, implementation, observation, and reflection involving students as much as 13 people. Data collection is done through observation sheets and test provision. The result of this research shows that the students activity cycle average is $64,9 \%$ and on the second cycle the average of student activity reach $77,8 \%$ and most of student have reached active criteria. On the result of student learning in cycle I that is 59,61 not yet completed by minimum masteri criteria but has reached the completeness in classical that is $76,92 \%$. The average grade obtained by students in the second cycle $74.61 \%$ and students' classical learning completeness on the second cycle increased to reach $92.3 \%$. Based on the results of research that has been done can be concluded that the application of problem solving learning can improve the activity and achievement of students in the learning process.
\end{abstract}

Keywords : Problem Solving, Human Circulation System, SMA Kristen YABT Manokwari.

\begin{abstract}
Abstrak
Penelitian ini bertujuan untuk meningkatkan aktivitas siswa dan kognitif prestasi siswa di IPA Kristen YABT Manokwari tahun ajaran 2017/2018 pada materi Sistem Sirkulasi Manusia dengan menerapkan Problem Solving Learning. Penelitian tindakan kelas dilakukan dalam dua siklus, setiap siklus terdiri dari empat tahap perencanaan, pelaksanaan, observasi, dan refleksi yang melibatkan siswa sebanyak 13 orang. Pengumpulan data dilakukan melalui lembar observasi dan ketentuan tes. Hasil penelitian menunjukkan bahwa rata-rata siklus aktivitas siswa adalah $64,9 \%$ dan pada siklus II rata-rata aktivitas siswa mencapai $77,8 \%$ dan sebagian besar siswa telah mencapai kriteria aktif. Pada hasil belajar siswa pada siklus I yaitu 59,61 belum diselesaikan oleh kriteria minimum masteri tetapi telah mencapai ketuntasan dalam klasik yaitu $76,92 \%$. Nilai rata-rata yang diperoleh siswa pada siklus II 74,61\% dan ketuntasan belajar siswa klasik pada siklus II meningkat hingga mencapai 92,3\%. Berdasarkan hasil penelitian yang telah dilakukan dapat disimpulkan bahwa penerapan pembelajaran problem solving dapat meningkatkan aktivitas dan prestasi belajar siswa dalam proses pembelajaran.
\end{abstract}

Kata kunci: Problem Solving, Sistem Sirkulasi Manusia, SMA Kristen YABT Manokwari.

1. Pendahuluan

Undang-Undang Dasar 1945 Pasal 31 Ayat (3) menetapkan bahwa pemerintah mengusahakan dan menyelengarakan suatu sistem pendidikan nasional, yang meningkatkan keimanan dan ketaqwaan serta akhlak mulia dalam rangka mencerdaskan kehidupan bangsa. Pernyataan tersebut menjelaskan bahwa pendidikan merupakan hak seluruh warga negara dan pemerintah wajib untuk memperhatikannya demi kemajuan negara. Melalui pendidikan yang baik, kita akan 
mudah mengikuti perkembangan jaman dimasa yang akan datang, khususnya perkembangan dalam Ilmu Pengetahuan Dan Teknologi (IPTEK).

Perkembangan pendidikan di Indonesia telah mengalami beberapa perubahan, termasuk kurikulum yang diberlakukan pada pendidikan formal. Sejak diresmikan pada tahun 2013, Kurikulum 2013 belum diberlakukan secara menyeluruh oleh satuan pendidikan khususnya di Papua. Kurikulum 2013 mengamanatkan penggunaan pendekatan ilmiah. Pendekatan ini memberikan kesempatan untuk meningkatkan kemampuan peserta didik dalam observasi, bertanya, menalar dan mengkomunikasikan pengetahuan yang diperoleh dari proses pembelajaran. Melalui tahapan-tahapan dalam pembelajaran yang berpendekatan saintifik, peserta didik dibimbing secara bertahap untuk mengorganisasikan dan memecahkan masalah dalam pembelajaran. Proses pembelajaran dengan pendekatan saintifik meliputi ranah kognitif, psikomotorik dan afektif melalui pengunaan sikap, keterampilan dan pengetahuan yang terintegrasi.

Salah satu faktor yang cukup penting dalam proses pelaksanaan pembelajaran yaitu metode dan model yang dipakai dalam pembelajaran. Menurut Damopolii dkk (2018) bahwa Model yang digunakan harus sesuai dengan tujuan pembelajaran serta jenis materi yang diajar. Penggunaan metode dan model pembelajaran merupakan hal yang harus diperhatikan, karena keberhasilan suatu proses pembelajaran tergantung pada suatu topik yang diajarkan, sehingga materi yang disampaikan oleh guru dapat diterima dengan baik oleh peserta didik. Pengunaan metode dan model pembelajaran yang baik merupakan tanggung jawab seorang guru. Guru harus bisa menempatkan, memilih metode dan model yang tepat agar proses pembelajaran dapat berlangsung dengan baik dan tidak bersifat monoton.

Berdasarkan observasi yang dilakukan peneliti selama kegiatan praktek pengalaman lapangan (PPL) pada tanggal 16 Januari s/d 25 Maret 2017 pada mata pelajaran IPA biologi bahwa dikelas XI SMA Kristen YABT Manokwari hanya terdapat satu rombongan belajar (kelas). Pada kelas tersebut terdapat permasalahan yang ditemui antara lain peserta didik belum berani bertanya dan memberikan pendapat sehingga terlihat pasif dan hasil belajar rendah. Pasif yang dimaksud adalah aktifitas peserta didik untuk belajar sangat rendah sehingga sulit untuk menimbulkan interaksi antara peserta didik dengan peserta didik, peserta didik dengan guru sehingga terlihat kelas didominasi oleh guru. Hal ini dapat dibuktikan dengan adanya sebagian peserta didik yang belum mencapai nilai ketuntasan minimal yaitu 60 .

Berdasarkan kenyataan yang ada maka perlu suatu model pembelajaran yang diharapkan peserta didik aktif dan mampu menyelesaikan masalah yaitu dengan menerapkan model pembelajaran Problem Solving. Model pembelajaran Problem Solving merupakan salah satu model pembelajaran yang membantu peserta didik mengembangkan kemampuan berpikir dan memecahkan masalah. Adanya permasalahan (problem) yang diberikan akan mengajak peserta didik menemukan solusi yang tepat (solving) melalui berdiskusi dengan kelompoknya. Hasil penelitian Damopolii, Nunaki dan Supriyadi (2018) menunjukkan model ini memiliki pengaruh terhadap peningkatan hasil belajar siswa. 
Dari latar belakang di atas maka penulis dalam penelitian ini mengambil judul “ Penerapan Model Pembelajaran Problem Solving Untuk Meningkatkan Keaktifan dan Hasil Belajar Peserta didik Pada Materi Sistem Peredaran Darah Manusia di Kelas XI IPA SMA Kristen YABT Manokwari Tahun Ajaran 2017/2018".

\section{Metode}

Metode penelitian yang digunakan adalah penelitian tindakan kelas. Penelitian tindakan kelas merupakan suatu kegiatan penelitian dengan mencermati sebuah kegiatan belajar yang diberikan tindakan, yang secara sengaja dimunculkan dalam sebuah kelas, yang bertujuan memecahkan masalah atau meningkatkan mutu pembelajaran dikelas tersebut (Arikunto,2006). Desain PTK dalam penelitian ini mengunakan model yang dikemukakan oleh Kemmis dan Mc Taggart (Mc.Taggart,2012) yang terdiri dari 4 tahapan yaitu perencanaan,pelaksanan, pengamatan dan refleksi. Model PTK seperti spiral dan berkelanjutan apabila target hasil tindakan yang dilakukan belum tercapai maka dilanjutkan dengan siklus berikutnya.

Prosedur Penelitian Tindakan Kelas

Prosedur penelitian ini terdiri dari dua siklus, dan masing-masing siklus terdiri dari 4 tahap yaitu perencanaan, pelaksanaan, pengamatan dan refleksi. Tahapan perencanaan ini disusun rencana tindakan yang akan dilakukan untuk meningkatkan keaktifan dan hasil belajar peserta didik melalui penerapan model problem solving.

\section{Siklus I}

Langkah perencanaan merupakan skenario yang dilakukan untuk melakukan tindakan, dimana didalamnya dilakukan kolaborasi antara peneliti dan guru pengampu. Perencanaan tindakan meliputi merencanakan jadwal tindakan, menentukan materi yang akan diajarkan, pembuatan RPP, persiapan bahan ajar, lembar observasi kegiatan guru, lembar observasi keaktifan peserta didik, lembar kerja peserta didik (LKS), soal tes.

\section{Pelaksanaan tindakan;}

Pada tahap ini peneliti melaksanakan tindakan sesuai dengan rencana pelaksanaan pembelajaran (RPP). Kegiatan yang dilakukan meliputi kegiatan awal, kegiatan inti dan kegiatan penutup. Penerapan pembelajaran dengan model problem solving adalah pembelajaran dengan sistem grup atau kelompok.

\section{Pengamatan}

Pada tahap observasi yang dilakukan untuk mengetahui keaktifan belajar peserta didik selama kegiatan pembelajaran sedang berlangsung dengan mengunakan lembar observasi keaktifan peserta didik yang telah dibuat. Pengamatan dilakukan oleh guru pengampu (observer 1) dan teman sejawat (observer 2).

\section{Refleksi}

Pada tahap ini kegiatan yang dilakukan adalah menganalisis hasil observasi dan hasil tes peserta didik, selanjutnya peneliti melakukan diskusi dengan observer untuk 
mengetahui hal apa saja yang telah tercapai dan kelemahan-kelemahan apa saja yang yang masih ada saat pembelajaran berlangsung. Dari hasil temuan tersebut selanjutnya akan dijadikan dasar untuk menyusun perbaikan pembelajaran yang akan dilakukan guru pada pembelajaran siklus ke-II.

\section{Siklus ke-2}

Perlakuan pada siklus II ini merupakan tindak lanjut dari kegiatan pembelajaran pada siklus I yang belum berhasil, yaitu menyusun kembali perbaikan yang dilakukan lagi pada siklus II. Sasarannya adalah untuk memperbaiki aspek-aspek yang dinilai belum berhasil pada siklus I. Langkah-langkah yang dilakukan pada siklus I dilakukan lagi pada siklus II dengan beberapa perbaikan yang mengacu pada hasil refleksi terhadap apa yang dilakukan selama proses pembelajaran. Tindakan ini sebagai tolak ukur meningkatkan keaktifan dan hasil belajar peserta didik dengan menerapkan model pembelajaran Problem Solving. Pada tahap ini juga dilakukan pengisian lembar pengamatan dan refleksi. Tujuan pelaksanaan tindakan ini adalah untuk meningkatkan keaktifan dan hasil belajar peserta didik seperti yang telah diamati pada siklus I.

\section{Kriteria Keberhasilan Tindakan Kelas}

Kriteria ketuntasan belajar biologi peserta didik kelas XI SMA Kristen YABT Manokwari dapat dinyatakan sebagai berikut:

a). Ketuntasan perorangan, seorang peserta didik dikatakan tuntas apabila telah mencapai nilai $\geq 60$ dari nilai maksimal 100 .

(b) Ketuntasan klasikal, suatu kelas dikatakan tuntas apabila terdapat minimal $75 \%$ yang telah mencapai nilai $\geq 60$ dari nilai maksimal 100,

(c) Pada keaktifan peserta didik, kompetensi yang diharapkan adalah $75 \%$ peserta didik mencapai kriteria aktif atau sangat aktif.

Teknik pengumpulan data yang akan digunakan adalah observasi dan teknik pengukuran. Data yang diperoleh dalam penelitian di ambil melalui lembar observasi kegiatan guru, lembar observasi keaktifan peserta didik serta hasil belajar peserta didik yang diperoleh melalui tes dengan mengunakan instrumen soal pilihan ganda.

\section{Teknik analisis data}

Analisis data yang digunakan pada penelitian ini adalah analisis deskriptif kualitatif. Analisis deskriptif kualitatif yaitu suatu metode penelitian yang menggambarkan kenyataan atau fakta sesuai dengan data yang diperoleh.Analisis deskriptif kualitatif dalam penelitian ini bertujuan untuk mengetahui hasil belajar dan keaktifan peserta didik terhadap kegiatan pembelajaran. Data keaktifan belajar peserta didik diperoleh dari pengamatan pada setiap siklus, selanjutnya data tersebut dianalisis secara kualitatif dengan persentase. Data hasil belajar peserta didik juga dilakukan analisis secara deskriptif dengan persentase pada masingmasing indikator yang dibuat pada setiap siklus.

a. Analisis data Keaktifan peserta didik

Lembar Observasi keaktifan peserta didik digunakan sebagai pedoman peneliti dalam mengamati keaktifan peserta didik pada pelaksanaan pembelajaran sistem peredaran darah manusia dengan model problem solving. Data keaktifan peserta didik dianalisis dengan cara deskriptif persentase dengan mengunakan rumus sebagai berikut (Wijayanti,2012). 
b. Analisis hasil belajar peserta didik

Nilai hasil belajar peserta didik terdiri atas nilai tes tertulis melalui evaluasi akhir dan melalui lembar diskusi peserta didik. Untuk menghitung capaian ketuntasan hasil belajar secara klasikal yaitu menurut Daryanto (2011).

\section{Hasil dan Pembahasan}

\section{Observasi Aktivitas Guru Siklus I}

Pada tahap ini dilakukan pengamatan untuk mengetahui aktivitas guru dalam menyampaikan pembelajaran. Pengamatan dilakukan oleh observer pada saat proses pembelajaran berlangsung dengan mengunakan model pembelajaran problem solving yang terdiri dari 10 aspek yang dinilai. Data aktivitas guru dapat dilihat pada tabel.1.

Tabel 1 Hasil Observasi Aktivitas Guru siklus I

\begin{tabular}{|c|c|c|}
\hline No & Aspek Yang Dicapai & $\begin{array}{l}\text { Capaian } \\
\%\end{array}$ \\
\hline 1 & Guru menyapa dan mengkondisikan kelas & 100 \\
\hline 2 & Memberikan apersepsi & 75 \\
\hline 3 & Menyampaikan judul dan tujuan pembelajaran & 100 \\
\hline 4 & Menjelaskan materi secara singkat & 100 \\
\hline 5 & $\begin{array}{l}\text { Membagi peserta didik dalam beberapa kelompok dan } \\
\text { membagikan LKS }\end{array}$ & 100 \\
\hline 6 & Membimbing peserta didik saat diskusi kelompok & 100 \\
\hline 7 & $\begin{array}{l}\text { Memberikan kesempatan kepada peserta didik untuk } \\
\text { menyampaikan pendapat/tanggapan }\end{array}$ & 75 \\
\hline 8 & Membimbing peserta didik saat mempresentasikan hasil & 100 \\
\hline 9 & Membimbing peserta didik menyimpulkan pembelajaran & 75 \\
\hline \multirow[t]{2}{*}{10} & Mengawasi peserta didik saat mengerjakan tes & 100 \\
\hline & Rata-Rata Capaian Aktivitas Guru & 92,5 \\
\hline
\end{tabular}

\section{Observasi Keaktifan Peserta didik Siklus I}

Table 2 Data Keaktifan Peserta Didik Siklus I

\begin{tabular}{ccccc}
\hline \multirow{2}{*}{ No } & $\begin{array}{c}\text { Nama } \\
\text { Responden }\end{array}$ & \multicolumn{2}{c}{ Capaian Siklus I } & Rata-rata (\%) \\
\cline { 3 - 4 } & & $\begin{array}{c}\text { Pertemuan } \\
\text { ke-1 }\end{array}$ & $\begin{array}{c}\text { Pertemuan } \\
\text { ke-2 }\end{array}$ & \\
\hline 1 & R 1 & 61,11 & 72,22 & 66,66 \\
2 & R 2 & 63,88 & 75 & 69,44 \\
3 & R 3 & 63,88 & 0 & 31,94 \\
4 & R 4 & 72,22 & 76,38 & 74,30 \\
5 & R 5 & 63,88 & 73,61 & 68,75 \\
6 & R 6 & 59,72 & 72,77 & 65,97 \\
7 & R 7 & 56,94 & 61,11 & 59,02 \\
8 & R 8 & 63,88 & 79,16 & 71,52 \\
9 & R 9 & 56,94 & 66,66 & 61,80 \\
10 & R 10 & 61,11 & 77,77 & 69,44 \\
11 & R 11 & 51,38 & 55,55 & 53,47 \\
12 & R 12 & 84,72 & 83,33 & 84,02 \\
13 & R 13 & 65,27 & 69,44 & 67,36 \\
\hline \multicolumn{2}{l}{ Rata-Rata Keaktifan } & 63,4 & 66,3 & 64,9 \\
\hline
\end{tabular}




\section{Hasil Belajar Peserta didik Siklus I}

Hasil belajar peserta didik diperoleh setelah peserta didik melakukan tes hasil belajar siklus I yaitu pada akhir pertemuan 1 dan pertemuan 2 dengan mengunakan model pembelajaran problem solving dapat dilihat pada tabel 3 dan evaluasi hasil belajar peserta didik disajikan pada tabel 3

Tabel 3 Data Hasil Belajar Siklus I

\begin{tabular}{|c|c|c|c|c|c|}
\hline \multirow[b]{2}{*}{ No } & \multirow{2}{*}{$\begin{array}{c}\text { Nama } \\
\text { Responden }\end{array}$} & \multicolumn{2}{|c|}{ Nilai Siklus I } & \multirow{2}{*}{$\begin{array}{l}\text { Rata- } \\
\text { rata }\end{array}$} & \multirow[b]{2}{*}{$\begin{array}{c}\text { Tuntas/ Tidak } \\
\text { tuntas }\end{array}$} \\
\hline & & $\begin{array}{l}\text { Pertemuan } \\
\text { ke-1 }\end{array}$ & $\begin{array}{l}\text { Pertemuan } \\
\text { ke- } 2\end{array}$ & & \\
\hline 1 & R 1 & 50 & 70 & 60 & Tuntas \\
\hline 2 & R 2 & 60 & 80 & 70 & Tuntas \\
\hline 3 & R 3 & 70 & 0 & 35 & Tidak tuntas \\
\hline 4 & R 4 & 60 & 60 & 60 & Tuntas \\
\hline 5 & R 5 & 50 & 70 & 60 & Tuntas \\
\hline 6 & R 6 & 60 & 60 & 60 & Tuntas \\
\hline 7 & R 7 & 40 & 60 & 50 & Tidak tuntas \\
\hline 8 & R 8 & 60 & 80 & 70 & Tuntas \\
\hline 9 & R 9 & 60 & 70 & 65 & Tuntas \\
\hline 10 & R 10 & 70 & 70 & 70 & Tuntas \\
\hline 11 & R 11 & 30 & 50 & 40 & Tidak tuntas \\
\hline 12 & R 12 & 70 & 80 & 75 & Tuntas \\
\hline 13 & R 13 & 50 & 70 & 60 & Tuntas \\
\hline \multicolumn{2}{|c|}{ Rata-Rata Kelas } & 56 & 63 & 59,61 & \\
\hline
\end{tabular}

Tabel 4. Evaluasi Hasil Belajar Peserta didik Siklus I

\begin{tabular}{lccc}
\hline \multicolumn{1}{c}{ Predikat } & Nilai & $\begin{array}{c}\text { Jumlah } \\
\text { peserta didik }\end{array}$ & Persentase \% \\
\hline Tuntas & $60-100$ & 10 & 76,92 \\
Tidak tuntas & $0-59$ & 3 & 23,08 \\
\hline \multicolumn{2}{c}{ Jumlah } & 13 & 100 \\
\hline
\end{tabular}

\section{Refleksi Siklus I}

Berdasarkan hasil analisis yang dilakukan pada lembar observasi keaktifan peserta didik, aktivitas guru, dan hasil belajar peserta didik pada siklus I, masih beberapa aspek yang masih perlu ditingkat lagi antaranya yaitu:

1. Aktivitas guru sudah dikatakan baik dalam menyampaikan pembelajaran yaitu 75\% namun masih perlu ditingkatkan.

2. Dalam penerapan model pembelajaran problem solving, sebagian besar peserta didik mendapatkan kesulitan dan belum aktif dalam berdiskusi karena peserta didik belum terbiasa memecahkan permasalahan dalam LKS mengunakan model problem solving.

3. Sebagian besar keaktifan peserta didik sudah baik hanya ada beberapa aspek seperti peserta didik harus lebih memperhatikan apa yang dijelaskan guru, peserta didik kurang membaca LKS dengan serius, sebagian besar peserta didik belum bertanya dan menanggapi presentasi kelompok lain dan peserta didik belum membuat rumusan masalah secara tepat. 
4. Ketuntasan hasil belajar siklus I, dihitung secara klasikal yaitu 76,92\%. Dari hasil perhitungan tersebut sudah memenuhi standar klasikal yaitu 75\%, namun nilai setiap peserta didik masih perlu ditingkatkan.

\section{Siklus II}

\section{a. Observasi Aktivitas Guru Siklus II}

Seperti pada siklus pertama, pada siklus II ini pengamatan juga dilakukan untuk mengetahui aktivitas guru dalam menyampaikan pembelajaran. Pengamatan juga dilakukan oleh observer pada saat proses pembelajaran berlangsung dengan mengunakan model pembelajaran problem solving yang terdiri dari 10 aspek yang dicapai. Data aktivitas guru dapat dilihat pada tabel 4.5

Tabel 5 Data Hasil Observasi Aktivitas Guru Siklus II

\begin{tabular}{llc}
\hline \multicolumn{2}{c}{ Data Analisis Observasi Aktivitas Guru Siklus II } \\
\hline No & \multicolumn{1}{c}{ Aspek Yang Dicapai } & Capaian \% \\
\hline 1 & Guru menyapa dan mengkondisikan kelas & 100 \\
2 & Memberikan apersepsi & 100 \\
3 & Menyampaikan judul dan tujuan pembelajaran & 100 \\
4 & Menjelaskan materi secara singkat & 100 \\
5 & Membagi peserta didik dalam beberapa kelompok dan & 100 \\
& dan membagikan LKS & 100 \\
6 & Membimbing peserta didik saat diskusi kelompok & 75 \\
7 & Memberikan kesempatan kepada peserta didik untuk & 100 \\
& menyampaikan pendapat/tanggapan & 100 \\
9 & Membimbing peserta didik saat mempresentasikan hasil & 100 \\
10 & Membimbing peserta didik menyimpulkan pembelajaran & 97,5 \\
\hline
\end{tabular}

Berdasarkan Tabel 4.6 yaitu hasil aktivitas guru oleh observer 1 dan observer 2 pada siklus II, dari 10 aspek yang diamati, ternyata ada 9 aspek yang mendapatkan kategori sangat baik sedangkan 1 aspek masih termasuk kategori baik. Rata-rata capaian aktivitas guru pada siklus dua mencapai 97,5\% dibandingkan dengan siklus I 92,5 \% dan pada siklus II ini terjadi peningkatan sebesar 5\%.

\section{b. Observasi Keaktifan Peserta didik Siklus II}

Tabel 6 Data Hasil Keaktifan Peserta didik Siklus II

\begin{tabular}{lcc}
\hline No & Nama & Capaian (\%) \\
\hline 1 & R 1 & 83,33 \\
2 & R 2 & 80,55 \\
3 & R 3 & 79,16 \\
4 & R 4 & 79,16 \\
5 & R 5 & 80,55 \\
6 & R 6 & 75 \\
7 & R 7 & 73,61 \\
8 & R 8 & 80,55
\end{tabular}




\begin{tabular}{ccc}
9 & R 9 & 72,22 \\
10 & R 10 & 81,94 \\
11 & R 11 & 62,5 \\
12 & R 12 & 87,5 \\
13 & R 13 & 76,38 \\
\hline
\end{tabular}

Berdasarkan data dalam tabel 6 rata-rata keaktifan peserta didik secara keseluruhan yang terdiri dari 6 aspek yang diamati pada siklus II didapatkan ratarata keaktifan peserta didik siklus II yaitu $77,8 \%$ dengan kriteria aktif. Jika dibandingkan dengan siklus I yaitu $64,9 \%$ dan pada siklus II ada peningkatan sebesar $12,9 \%$.

\section{c. Hasil Belajar Peserta didik Siklus II}

Hasil belajar peserta didik diperoleh setelah peserta didik melakukan tes hasil belajar siklus II dengan mengunakan model pembelajaran problem solving dapat dilihat pada Tabel 7 dan evaluasi hasil belajar peserta didik disajikan pada Tabel 4.8 berikut.

Tabel 7 Data Hasil Belajar Siklus II

\begin{tabular}{|c|c|c|c|}
\hline No & Nama responden & Nilai siklus II & Tuntas/Tidak Tuntas \\
\hline 1 & R 1 & 70 & Tuntas \\
\hline 2 & R 2 & 80 & Tuntas \\
\hline 3 & R 3 & 70 & Tuntas \\
\hline 4 & R 4 & 80 & Tuntas \\
\hline 5 & R 5 & 80 & Tuntas \\
\hline 6 & R 6 & 70 & Tuntas \\
\hline 7 & R 7 & 60 & Tuntas \\
\hline 8 & R 8 & 90 & Tuntas \\
\hline 9 & R 9 & 70 & Tuntas \\
\hline 10 & $\mathrm{R} 10$ & 80 & Tuntas \\
\hline 11 & R 11 & 50 & Tidak tuntas \\
\hline 12 & R 12 & 90 & Tuntas \\
\hline \multirow[t]{2}{*}{13} & R 13 & 80 & Tuntas \\
\hline & ta-Rata Kelas & 74,61 & \\
\hline
\end{tabular}

Tabel 8 Evaluasi Hasil Belajar Peserta didik Siklus II

\begin{tabular}{cccc}
\hline Predikat & Nilai & $\begin{array}{c}\text { Jumlah } \\
\text { peserta } \\
\text { didik }\end{array}$ & Persentase \% \\
\hline Tuntas & $60-100$ & 12 & 92,3 \\
Tidak tuntas & $0-59$ & 1 & 7,7 \\
\hline \multicolumn{2}{c}{ Jumlah } & 13 & 100 \\
\hline
\end{tabular}




\section{d. Refleksi Siklus II}

Berdasarkan hasil analisis data keaktifan peserta didik, data aktivitas guru dan hasil belajar peserta didik terhadap proses pembelajaran bahwa sebagian besar keseluruhannya sudah baik dikarenakan guru sudah berusaha lebih baik dalam membimbing peserta didik, selain itu juga peserta didik sudah terbiasa mengunakan model pembelajaran problem solving. Pada keaktifan peserta didik mengalami peningkatan sebesar $12,9 \%$ dari rata-rata capaian keaktifan peserta didik pada siklus I yaitu $64,9 \%$ meningkat menjadi $77,8 \%$ pada siklus II. Proses pembelajaran mengunakan model problem solving dapat memberikan kesempatan kepada peserta didik untuk belajar memecahkan permasalahan yang diberikan oleh guru. Pada evaluasi hasil belajar, ketuntasan hasil belajar peserta didik secara klasikal pada siklus I yaitu 76,96\% dan pada siklus II meningkat menjadi 92,30\%. Karena proses pembelajaran yang dilakukan menjadi lebih baik sehingga meningkatkan keaktifan dan hasil belajar peserta didik maka peneliti dan observer sepakat untuk tidak melanjutkannya ke siklus selanjutnya.

\section{Pembahasan}

\section{Aktivitas Guru}

Peningkatan keaktifan dan hasil belajar peserta didik tidak lepas dari peran guru. Kinerja guru yang baik dapat memberikan kontribusi yang baik terhadap proses pembelajaran khususnya peningkatan hasil belajar peserta didik.

Berdasarkan hasil observasi aktivitas guru yang dilakukan oleh observer yang mencakup 10 aspek yang dicapai yaitu guru menyapa dan mengkondisikan kelas, memberikan apersepsi, menyampaikan judul dan tujuan pembelajaran, membagi peserta didik dalam beberapa kelompok dan membagikan LKS, membimbing peserta didik saat diskusi kelompok memberikan kesempatan kepada peserta didik untuk menyampaikan pendapat/tanggapan, membimbing peserta didik saat mempresentasikan hasil, membimbing peserta didik menyimpulkan pembelajaran dan mengawasi peserta didik saat mengerjakan tes. Pada siklus I rata-rata presentasi aktivitas guru mencapai 93\% dan siklus II rata-rata aktivitas guru meningkat mencapai 98\%. Aktivitas guru pada pelaksanaan siklus I sudah berkriteria baik. Hanya saja, guru belum terbiasa mengunakan mengunakan model pembelajaran problerm solving sehingga guru kurang memberikan apersepsi, kurang memberikan kesempatan kepada peserta didik untuk mengemukakan pendapat serta kurang membantu peserta didik dalam menyimpulkan pembelajaran. Sedangkan pada siklus II guru sudah mulai terbiasa mengunakan model pembelajaran problem solving sehingga proses pembelajaran dapat terlaksanakan dengan baik walaupun guru masih terlihat mendominasi pembelajaran meskipun sudah ada kemajuan untuk memberikan kesempatan kepada peserta didik untuk mengemukakan pendapat. Kinerja guru dapat mempengaruhi hasil belajar peserta didik karena peran guru didalam pembelajaran adalah sebagai fasilitator, motivator dan membimbing kegiatan pembelajaran. Hal tersebut sejalan dengan pendapat Suparlan (2009) bahwa kreativitas guru juga mutlak diperlukan agar dapat merencanakan kegiatan pembelajaran yang menarik bagi peserta didik.

\section{Keaktifan Peserta Didik}

Berdasarkan data hasil penilaian oleh observer 1 guru mata pelajaran biologi dan observer 2 teman sejawat yang terdiri dari beberapa aspek penilaian. Pada penerapan model pembelajaran problem solving pada siklus I rata-rata keaktifan 
peserta didik mencapai $64,9 \%$. Pada siklus I ini sebagian besar peserta didik belum mencapai kriteria aktif atau sangat aktif. Hal ini dikarenakan masih banyak peserta didik yang masih belum terbiasa dan merasa kesulitan dengan model pembelajaran yang diterapkan, beberapa peserta didik memang sulit diajak untuk aktif didalam kelas karena peserta didik merasa kurang tertarik dalam pembelajaran. Kekurang tertarikan terhadap sesuatu akan menyebabkan peserta didik enggan melakukan sesuatu (Suparlan 2009). Namun pada siklus II rata-rata keaktifan peserta didik mencapai $77,8 \%$ dan sebagian besar peserta didik sudah mencapai kriteria aktif, sehingga dapat dikemukakan bahwa terjadi peningkatan keaktifan peserta didik pada siklus II. Kemampuan peserta didik dalam diskusi jadi lebih baik dari siklus I. Hal ini karena, disiklus II kerjasama antar kelompok sudah terlihat. Menurut Setiawan, 2008 diskusi yang berdasarkan pada masalah akan melatih peserta didik untuk belajar sekaligus mengajari teman lain melalui komunikasi yang efektif tentang apa yang diketahui maupun apa yang tidak diketahuinya. Hal ini akan meningkatkan kemampuan berpikir peserta didik melalui kemampuan bertanya dan menjawab peserta didik terhadap permasalahan yang diberikan.

\section{Hasil Belajar Peserta didik.}

Pada penelitian ini salah satu data yang diperoleh adalah data hasil belajar peserta didik pada mata pelajaran sistem peredaran darah manusia dengan menerapkan model pembelajaran problem solving. Hasil belajar peserta didik diperoleh dari tes hasil belajar secara individu disetiap akhir siklus, dimana setiap tes terdiri dari 10 butir soal pilihan ganda. Hasil belajar peserta didik mengambarkan hasil kemampuan yang dimiliki oleh peserta didik-peserta didik tersebut dalam mencapai pendidikan selama proses pembelajaran.

Pada penelitian ini hasil belajar dikatakan tuntas apabila peserta didik tersebut mencapai nilai 60 sesuai dengan KKM yang sudah ditetapkan di SMA Kristen YABT Manokwari. Penelitian ini dilakukan dikelas XI IPA dengan jumlah peserta didik 13 orang. Pada siklus I pertemuan pertama dilaksanakan pada tanggal 20 November 2017 dan pertemuan kedua dilaksanakan pada tanggal 22 November 2017. Pada siklus I peserta didik yang mencapai ketuntasan minimal 60 sebanyak 10 peserta didik sedangkan peserta didik yang tidak mencapai ketuntasan minimal berjumlah 3 orang peserta didik. Nilai rata-rata kelas yang diperoleh pada siklus I yaitu 59,61 belum tuntas secara KKM namun sudah mencapai ketuntasan secara klasikal yaitu 76,92\%. Meskipun belum semua peserta didik mencapai kriteria ketuntasan minimal, namun hal ini menunjukkan bahwa model pembelajaran problem solving dapat mengatasi hasil belajar peserta didik karena peserta didik tidak hanya mendengarkan guru mengajar tetapi juga melakukan sesuatu dan bekerja sama dengan dengan peserta didik lain. Hal ini sesuai dengan pilar pendidikan menurut UNESCO dalam Suparlan, 2009 yaitu learning to do yang mengajarkan peserta didik untuk untuk bersosialisasi melalui kegiatan berdiskusi dan menurut Sanjaya, 2006 dengan memecahkan masalah dan berdiskusi bersama akan mudah memahami isi pembelajaran. Berdasarkan data hasil dan refleksi pada Siklus I, peneliti dan observer sepakat melanjutkan ke Siklus II untuk memperbaiki kekurangankekurangan pada siklus I.

Pada siklus II dilaksanakan pada tanggal 24 November dengan materi yang diajarkan adalah alat-alat peredaran darah dan kemungkinan penyakit yang terjadi pada peredaran darah. Dari proses pembelajaran tersebut, peserta didik yang mencapai ketuntasan belajar berdasarkan ketuntasan minimal yaitu 60 sebanyak 12 
peserta didik dan peserta didik yang tidak mencapai ketuntasan sebanyak 1 orang peserta didik dari 13 orang yang peserta didik yang mengikuti tes. Nilai rata-rata kelas yang diperoleh oleh peserta didik pada siklus II yaitu 74,61 dan ketuntasan klasikal belajar peserta didik pada siklus II meningkat mencapai 92,3\%. Pada siklus II ini rata-rata nilai yang diperoleh peserta didik mengalami peningkatan sebesar 15\%. Peningkatan hasil belajar terjadi karena peserta didik semakin aktif dan konsentrasi dalam pembelajaran yaitu memperhatikan guru saat menjelaskan dan melakukan diskusi dengan baik. Pada siklus II peserta didik sudah terbiasa mengunakan model pembelajaran problem solving. Peningkatan hasil belajar ini sebagai bukti bahwa problem solving yang diterapkan dikelas XI IPA SMA Kristen YABT Manokwari yang dirancang dengan diskusi kelompok mampu meningkatkan keaktifan dan hasil belajar peserta didik. Menurut Iwan dkk (2018) bahwa siswa yang terlibat dalam pemecahan masalah siswa dapat memecahkan masalah secara mandiri dalam kelompok diskusi. Hal ini karena didalam problem solving terdapat tahapan-tahapan yang mendukung proses ilmiah seperti merumuskan masalah, menganalisis masalah, merumuskan hipotesis, mengumpulkan data, menguji hipotesis dan menarik kesimpulan. Hal ini akan mengajak peserta didik aktif dan lebih mudah memahami materi dan memecahkan permasalahan. Permasalahan yang diberikan sudah sesuai dengan kemampuan peserta didik (Sanjaya 2006), sehingga peserta didik mampu mempelajari IPA Biologi dengan mudah (Setiawan 2008).

\section{Simpulan}

Berdasarkan hasil penelitian yang telah dilakukan pada siklus I dan siklus I, maka data disimpulkan sebagai berikut.

1. Penerapan model pembelajaran problem solving dapat meningkatkan keaktifan peserta didik dalam proses pembelajaran. Berdasarkan hasil observasi keaktifan peserta didik siklus I dan siklus II, presentasi keaktifan peserta didik pada siklus I yaitu $64,9 \%$ dan mengalami peningkatan pada siklus II yaitu 77,8\%. Jadi ada peningkatan sebesar $12,9 \%$.

2. Penerapan model pembelajaran problem solving dapat meningkatkan hasil belajar peserta didik, hal ini dapat dilihat pada hasil evaluasi belajar peserta didik pada siklus I dan siklus II. Rata-rata hasil belajar peserta didik pada siklus I sebesar 59,61 namun sudah dapat dihitung secara klasikal yaitu 76,92\% dan mengalami peningkatan pada siklus II yang mencapai rata-rata 74,61 , dan juga sudah memenuhi ketuntasan secara klasikal yaitu 92,30\%.

\section{Referensi}

Arikunto S. (2016). Prosedur Penelitian. Edisi Revisi Keenam. Jakarta: Penerbit Pt Rineka Cipta

Damopolii, I., Yohanita, A. M., Malatta, F. H \& Yusuf, F. M. (2018). Pengaruh Model Pembelajaran Berbasis Masalah terhadap Hasil Belajar Kognitif Siswa Kelas VII SMP. Edubiotik. 3(1). 43-52

Damopolii, I., Nunaki, J. H., \& Supriyadi, G. (2018). Effect of Problem Solving Learning Model on Students Achievement. Journal of Education Research and Evaluation, 2(1).

Daryanto. (2011). Penelitian Tindakan Kelas Dan Penelitian Tindakan Sekolah Beserta Contoh-Contohnya. Yogyakarta: Gava Media 
Kemmis, S dan Mc Taggart, R. (2012). Penelitian Tindakan Kelas. Malang: Bayu Media,Cet Ke-7

Iwan, I., Korwa, E. L., \& Wambrauw, H. L. (2018). Peningkatkan hasil belajar peserta didik melalui penerapan model pembelajaran problem based learning pada materi sistem pencernaan manusia di kelas Viii A SMPN 13 Manokwari. Jurnal Nalar Pendidikan, 6(1), 32-40.

Sanjaya, W. (2006). Strategi Pembelajaran Berbasis Standar Proses Pendidikan. Jakarta : Penerbit Kanisius

Setiawan, I. (2008). Penerapan Pengajaran Kontekstual Berbasis Masalah Untuk Meningkatkan Hasil Belajar Biologi Peserta didik Kelas X SMA Laboratorium 2 Singaraja

Suparlan. (2009). PAKEM pembelajaran aktif, kreatif, efektif dan menyenangkan. Bandung. Penerbit PT Genesind

Wijayanti. (2012). Peningkatan Keaktifan Peserta didik Mengunakan Pendekatan Kontekstual Berbasis Hands On Activity pada IPA Tema Pencemaran Air Kelas VII di SMP N 1 Segeyan. Skripsi Tidak Diterbitkan, Yogyakarta, UNY 